\title{
ЦЕЛИ АНТИКОРРУПЦИОННОГО МОНИТОРИНГА КАК ДИАГНОСТИЧЕСКОГО ИНСТРУМЕНТА РЕГИОНАЛЬНОЙ АНТИКОРРУПЦИОННОЙ ПОЛИТИКИ: СРАВНИТЕЛЬНО-ПРАВОВОЕ ИССЛЕДОВАНИЕ
}

$\Pi$ оследовательное, системное, наступательное и рациональное противодействие коррупции, свидетельствующее о необратимости этого процесса невозможно без диагностики происходящих процессов в обществе. В качестве средства такой диагностики российское региональное законодательство закрепило антикоррупционный мониторинг. Закрепление в антикоррупционном законодательстве и подзаконных нормативных правовых актов антикоррупционного мониторинга - начальный и важнейший организационно-правовой этап в процессе использования этого измерительного инструмента результативности региональной антикоррупционной политики. Однако, как любое мониторинговое исследование антикоррупционный мониторинг должен иметь свои цели и задачи, которые могут отражаться в региональном антикоррупционном законодательстве и/или подзаконных нормативных правовых актах, регулирующих его организацию и проведение. Обычно, региональные правотворческие органы при подготовке нормативных правовых актов используют уже разработанные наукой положения. Необходимо отметить, что в современной российской специальной литературе в качестве целей антикоррупционного мониторинга указывается на выявление закономерностей изменения состояния коррупции для обеспечения разработки и реализации антикоррупционных программ и антикоррупционных мер ${ }^{1}$. Безусловно, это узкий подход к содержанию основных целей регионального антикоррупционного мониторинга, который нуждается в качественном научном обновлении и расширении.

\footnotetext{
Бикеев И.И., Бикмухаметов А.Э., Газимзянов Р.Р. и др. Коррупция и антикоррупционная политика: Терминологический словарь / под общ. ред. Г.И. Райкова, П.А. Кабанова, Д.К. Чиркова. - М., 2010. - С. 83; Хазанов С.Д. К вопросу о формировании механизмов оценки эффективности мер противодействия коррупции в Российской Федерации // Следователь. - 2013. - №1. - С. 58-59; Павленко О.В. Антикоррупционный мониторинг - необходимое условие антикоррупционных мероприятий // Следователь. - 2013. - №4. - С.51.
}

Как нам представляется, антикоррупционный мониторинг - это измерительный инструмент состояния коррупции, её причин и эффективности принимаемых антикоррупционных мер. Следовательно, его основная цель должна быть несколько иной - точность или объективность, насколько это возможно в современных условиях, измерения состояния коррупции, её причин и результативности, принимаемых антикоррупционных мер для последующей корректировки региональной и/или муниципальной антикоррупционной политики.

Как нам представляется, при организации и осуществлении регионального антикоррупционного мониторинга можно выделить цели-направления и цели-задачи. Цели-направления - это деятельность субъектов антикоррупционного мониторинга, направленная на достижение определенного результата, заложенного в региональном антикоррупционном законодательстве. Цели-задачи - это деятельность субъектов антикоррупционного мониторинга, направленная на достижение результата на данный момент благодаря наличию у организаторов и исполнителей необходимых ресурсов и условий. Ингода такие цели регионального антикоррупционного мониторинга именуют промежуточными или просто задачами.

Обратившись к сравнительно-правовому анализу регионального антикоррупционного законодательства, мы обнаруживаем, что оно, как правило, содержит в себе указание на цели-направления регионального антикоррупционного мониторинга. Из всей совокупности исследованных нами действующих антикоррупционных законов субъектов РФ в 53 или 63,9\% из них имеется прямое указание на цели-направления этого диагностического инструмента антикоррупционной деятельности.

Как показывает практика регионального законотворчества, основными рациональными целями антикоррупционного мониторинга, закрепленными в региональном антикоррупционном законодательстве являются: обеспечение оценки эффективности (ре- 
зультативности) антикоррупционных мер (мер антикоррупционной политики и/или антикоррупционных программ) и обеспечение разработки и реализации антикоррупционных программ (планов противодействия коррупции). Достижение первой цели предусмотрено в 46 или 55,4\% всех действующих региональных антикоррупционных законах, а достижение второй цели закреплено в 36 или 43,4\%.

Однако, в региональном антикоррупционном законодательстве, помимо указанных нами выше целей антикоррупционного мониторинга, встречаются и иные рациональные цели. Такими целями обычно признаются:

- своевременное приведение нормативных правовых актов органов государственной власти и органов местного самоуправления в соответствии с федеральным и/или региональным законодательством, в том числе и антикоррупционном - в 9 и 10,8\% региональных антикоррупционных законах (Владимирская², Калужская ${ }^{3}$, Нижегородская ${ }^{4}$ и Амурская 5 области, Санкт-Петербург ${ }^{6}$, Республика Ингушетия ${ }^{7}$, Чеченская Республика ${ }^{8}$ Республика Чувашия ${ }^{9}$ и Республика Бурятия ${ }^{10}$ );

2 О противодействии коррупции во Владимирской обл.: Закон Владимирской обл. от 10.11.2008 №181-О3 (ред. от 11.03.2011) // Владимирские ведомости. - 2008. - 19 нояб.

3 О противодействии коррупции в Калужской обл.: Закон Калужской обл. от 27.04.2007 №305-О3 (ред. от 10.11.2009) // Весть. $-2009-3$ июня.

4 О противодействии коррупции в Нижегородской обл. “Закон Нижегородской области от 07.03.2008 №20-3 (ред. от 07.02.2011) // Правовая среда. - 2008. - 20 марта.

5 О мерах по противодействию коррупции в Амурской обл.: Закон Амурской обл. от 08.04.2009 №191-О3 (ред. от 05.07.2010) // Амурская правда. - 2009. - 15 апр.

6 О дополнительных мерах по противодействию коррупции в Санкт-Петербурге: Закон Санкт-Петербурга от 11 ноября 2008 г. №674-122 // Санкт-Петербургские ведомости. 2008. - 28 нояб.

7 О противодействии коррупции в Республике Ингушетия: Закон Республики Ингушетия от 04.03.2009 №8-Р3 // Ингушетия. - 2009. - 12 марта.

8 О противодействии коррупции в Чеченской Республике: Закон Чеченской Республики от 21 мая 2009 г. №36-P3 // Вести республики. $-2009 .-10$ июня.

9 О противодействии коррупции: Закон Чувашской Республики от 04.06.2007 №14 (ред. от 19.11.2010) // Собрание законодательства Чувашской Республики. - 2007. - №5. - Ст. 253.

10 О противодействии коррупции в Республике Бурятия: Закон Республики Бурятия от 16.03.2009 №701-IV (ред. от 11.03.2011) // Собрание законодательства Республики Бурятия. - 2009. - №1-2(118-119).
- выявление и устранение причин коррупции (Ивановская ${ }^{11}$ и Курганская ${ }^{12}$ области);

- реализация мер противодействия коррупции (Тульская область ${ }^{13}$ );

- разработка нормативных правовых актов (Ярославская область $\left.{ }^{14}\right)$;

- повышение эффективности мер по реализации антикоррупционной политики (Республика Карелия ${ }^{15}$, Волгоградская ${ }^{16}$ и Псковская ${ }^{17}$ области);

- оценка реализации полномочий органов власти в сфере противодействия коррупции (Вологодская ${ }^{18}$ область);

- выявление в нормативных правовых актах коррупциогенных факторов (Вологодская ${ }^{19}$, Иркутская $^{20}$, Челябинская ${ }^{21}$ области);

11 О противодействии коррупции в Ивановской обл.: Закон Ивановской обл. от 18.06.2009 №61-О3 (ред. от 16.12.2009) // Ивановская газета. - 2009. - 19 июня.

12 О противодействии коррупции в Курганской обл.: Закон Курганской обл. от 03.03.2009 №439 (ред. от 04.05.2010) // Новый мир. - 2009. - 11 марта.

13 Об отдельных мерах по противодействию коррупции в Тульской обл.: Закон Тульской обл. от 12.11.2008 №1108ЗТО (ред. от 07.10.2009) // Тульские известия. - 2008. 20 нояб.

14 О мерах по противодействию коррупции в Ярославской обл.: Закон Ярославской обл. от 09.07.2009 №40-з (ред. от 28.12.2010) // Губернские вести. - 2009. - 13 июля.

15 О противодействии коррупции: Закон Республики Карелия от 23.07.2008 №1227-3РК(ред. от 03.03.2010)//Карелия.2008. - 5 авг.

16 О дополнительных мерах по противодействию коррупции в Волгоградской обл.: Закон Волгоградской обл. от 13.07.2009 №1920-ОД (ред. от 20.04.2011) // Волгоградская правда. - 2009. - 22 июля.

17 О противодействии коррупции в органах государственной власти Псковской обл. и органах местного самоуправления: Закон Псковской обл. от 17.07.2008 №784-оз (ред. от 31.12.2010) // Псковская правда. - 2008. - 24 июля.

18 О противодействии коррупции в Вологодской области: закон Вологодской обл. от 09.07.2009 №2054-О3 (ред. от 27.09.2010) // Красный Север. - 2009. - 18 июля.

19 Там же.

20 О противодействии коррупции в Иркутской обл.: Закон Иркутской обл. от 13.10.2010 №92-О3 // Областная. - 2010. 20 октяб.

21 О противодействии коррупции в Челябинской обл.: Закон Челябинской обл. от 29.01.2009 №353-3О (ред. от 24.12.2009) // Южноуральская панорама. - 2009. 13 февр. 
- оценка состояния коррупции (Ленинградская область ${ }^{22}$, Алтайский ${ }^{23}$ и Красноярский ${ }^{24}$ края);

- предупреждение коррупционных правонарушений (Ставропольский край ${ }^{25}$ );

- своевременное принятие решений государственными органами, направленных на противодействие коррупции (Республика Башкортостан ${ }^{26}$ );

- информирование о состоянии противодействия коррупции и подготовка предложений органам, реализующим меры противодействия коррупции $\left(\right.$ Республика Башкортостан ${ }^{27}$ );

- наблюдения эффективности реализации мер пресечения и привлечения к ответственности за коррупционные правонарушения (Пермский ${ }^{28}$ край);

- разработка прогнозов состояния и тенденций развития антикоррупционной политики (Пермский ${ }^{29}$ и Красноярский ${ }^{30}$ края, Республика Тыва ${ }^{31}$, Респу-

22 О противодействии коррупции в органах государственной власти Ленинградской обл. и органах местного самоуправления Ленинградской обл.: Областной закон Ленинградской обл. от 8 февраля 2010 г. №1-оз // Вестник Правительства Ленинградской обл. - 2010. - 13 февр.

23 О противодействии коррупции в Алтайском крае: Закон Алтайского края от 03.06.2010 № 46-3С // Сборник законодательства Алтайского края. - 2010. - №170. ч. 1. июнь. - С. 22.

24 О противодействии коррупции в Красноярском крае: Закон Красноярского края от 07.07.2009 №8-3610 (ред. от 10.06.2010) // Ведомости высших органов государственной власти Красноярского края. - 2009. - №37(333). 27.07.

25 О противодействии коррупции в Ставропольском крае: Закон Ставропольского края от 04.05.2009 №25-кз (ред. от 24.12.2010) // Сборник законов и других правовых актов Ставропольского края. - 2009. - №14. - Ст. 8301.

26 О противодействии коррупции в Республике Башкортостан: Закон Республики Башкортостан от 13.07.2009 №145-3 (ред. от 18.03.2011) // Ведомости Государственного Собрания - Курултая, Президента и Правительства Республики Башкортостан. - 2009. - №17(311). - Ст. 1087.

27 Там же.

28 О противодействии коррупции в Пермском крае: Закон Пермского края от 30.12.2008 №382-ПК (ред. от 10.05.2011) // Собрание законодательства Пермского края. - 2009. - №2. II часть. 25.02.

29 Там же.

30 О противодействии коррупции в Красноярском крае: Закон Красноярского края от 07.07.2009 №8-3610 (ред. от 10.06.2010) // Ведомости высших органов государственной власти Красноярского края. - 2009. - №37(333). 27.07.

31 О мерах по противодействию коррупции в Республике Тыва: Закон Республики Тыва от 07.07.2008 №856 ВХ-2 (ред. от 20.12.2010) // Тувинская правда. - 2008. - 21 авг. блика Хакасия ${ }^{32}$, Оренбургская $^{33}$ и Липецкая ${ }^{34}$ области).

Учитывая диагностический инструментальный характер антикоррупционного мониторинга можно предположить, что в большинстве региональных антикоррупционных законах, точно сформулирована одна из основных его целей - измерение результативности мер противодействия коррупции. В меньшей степени региональные законодательные (представительные) органы обратили внимания на две других основных цели - измерение (оценка) состояния коррупции и оценку причин коррупции в регионах и муниципальных образованиях. Остальные цели антикоррупционного мониторинга, предусмотренные региональным антикоррупционным законодательством являются дополнительными или факультативными. Однако следует иметь в виду, что целеполагание антикоррупционного мониторинга содержится не только в региональном антикоррупционном законодательстве, но и в подзаконных нормативных правовых актах, направленных на его правовое регулирование, организацию и проведение в субъектах РФ. Необходимо уточнить, что такое правовое регулирование возможно не только на региональном, но и на муниципальном уровне.

Анализ подзаконных нормативных правовых актов, регулирующих организацию и осуществление антикоррупционного мониторинга в субъектах РФ, показал, что в них по-разному обозначаются его основные цели. В одних региональных нормативных правовых актахставится одна основная (главная) цель, вдругихнесколько самостоятельных целей. В нормативных правовых актах, где указывается одна основная цель, преобладает указание на реализацию федерального и регионального антикоррупционного законодатель-

\footnotetext{
32 О противодействии коррупции в Республике Хакасия: Закон Республики Хакасия от 04.05.2009 №28-3РХ (ред. от 23.12.2010) // Вестник Хакасии. - 2009. - 8 мая.

33 О противодействии коррупции в Оренбургской обл.: Закон Оренбургской обл. от 15.09.2008 №2369/497-IV-O3 (ред. от 17.11.2010) // Южный Урал. - 2008. - 27 сентяб.

34 О предупреждении коррупции в Липецкой обл.: Закон Липецкой обл. от 07.10.2008 №193-ОЗ (ред. от 18.08.2010) // Липецкая газета. - 2008. - 17 октяб.
} 
ства (Республика Татарстан ${ }^{35}$, Ярославская ${ }^{36}$ и Смоленская ${ }^{37}$ области), либо федеральных и региональных подзаконных нормативных правовых актов по противодействию коррупции (Липецкая ${ }^{38}$ и Оренбургская ${ }^{39}$ области). В тех случаях, когда в нормативном правовом акте ставится несколько целей, то наибольшее количество упоминаний набирает цель - объективная оценка антикоррупционных мер (антикоррупционной политики) в субъекте РФ. Одной из основных целей антикоррупционного мониторинга она предусмотрена в подзаконных нормативных правовых актах Республики Дагестан ${ }^{40}$, Удмуртской Республики ${ }^{41}$, Республики Якутия ${ }^{42}$, Республики Калмыкия ${ }^{43}$,

35 О мерах по организации и проведению мониторинга эффективности деятельности органов исполнительной власти Республики Татарстан, территориальных органов федеральных органов исполнительной власти по Республике Татарстан, органов местного самоуправления муниципальных районов и городских округов Республики Татарстан по реализации антикоррупционных мер на территории Республики Татарстан: Указ Президента Республики Татарстан от 23 марта 2011 г. №УП-148 // Сборник постановлений и распоряжений Кабинета Министров Республики Татарстан и нормативных актов республиканских органов исполнительной власти. - 2011. - №11. - №18. - Ст. 0636.

36 Об осуществлении антикоррупционного мониторинга соблюдения требований законодательства о противодействии коррупции: Указ Губернатора Ярославской обл. от 7 июня 2012 г. № 256 // Документ-Регион. - 2012. - 13 июня.

37 Об утверждении Порядка проведения в Смоленской обл. антикоррупционного мониторинга: распоряжение Администрации Смоленской обл. от 01.04.2010 № 369 - р/адм.

38 О регулярном антикоррупционном мониторинге: Постановление администрации Липецкой обл. от 30 октября 2009 г. №370// Липецкая газета. - 2009. - 11 декаб.

39 О создании совета по антикоррупционной политике при Губернаторе Оренбургской обл.: Указ Губернатора Оренбургской обл. от 09.03.2010 №36-ук //Оренбуржье Официальное. - 2010. - 23 марта.

40 О порядке осуществления антикоррупционного мониторинга: Постановление Правительства Республики Дагестан от 20 апреля 2012 г. №119 // Собрание законодательства Республики Дагестан. - 2012. - №8. - Ст. 312.

41 О порядке проведения антикоррупционного мониторинга: Распоряжение Президента Удмуртской Республики от 15 октября 2012 г. №299-РП.

42 Об утверждении Положения о порядке проведения антикоррупционного мониторинга в Республике Саха (Якутия): Постановление Правительства Республики Саха (Якутия) от 30 августа 2012 г. №389 // Якутские ведомости. - 2012. - 8 сентяб.

43 О Методике осуществления антикоррупционного мониторинга эффективности системыпротиводействия коррупции в органах исполнительной власти Республики Калмыкия, руководство деятельностью которых осуществляется Правительством Республики Калмыкия: Распоряжение Правительства Респу-
Калининградской ${ }^{44}$, Новосибирской ${ }^{45}$, Калужской ${ }^{46}$, Ростовской ${ }^{47}$ и Ивановской ${ }^{48}$ областях, Красноярского ${ }^{49}$ и Пермского ${ }^{50}$ краев.

В процессе сравнительно-правового анализа целей антикоррупционного мониторинга заложенного в региональном антикоррупционном законодательстве и подзаконных нормативных правовых актах, направленных на его организацию и проведение выяснилось, что в значительной доле они не совпадают. В одних субъектах РФ цели антикоррупционного мониторинга, заложенные в региональном антикоррупционном законодательстве, по объему и содержанию значительно шире, чем в подзаконных нормативных правовых актах, в других - наоборот цели антикоррупционного мониторинга, предложенные в подзаконных нормативных актах по объему и содержанию шире, чем в региональном антикоррупционном законодательстве. Так, в соответствии с содержанием ст. 10 Закона Ре-

блики Калмыкия от 8 июня 2012 г. №108-p //http://www.corrupcii. net/index.php?option $=$ com_content $\&$ view $=$ article $\&$ id $=126 \% 3 \mathrm{~A}---$ -8--2012--n-108-\&catid=35\%3A2011-08-09-10-50-12\&Itemid=27

44 О порядке проведения антикоррупционного мониторинга: Постановление Правительства Калининградской обл. от 23 мая 2012 г. №350 // Калининградская правда. - 2012. - 30 мая.

45 Об утверждении Порядка проведения антикоррупционного мониторинга: Постановление Правительства Новосибирской обл. от 20 октября 2011 г. №458-п (в ред. от 18 июня 2012 г. №299-п) // Сборник нормативных правовых актов органов государственной власти Новосибирской области. 2011. - №4 (16). - Ч. 1. - Ст. 1078.

46 О проведении ежегодного антикоррупционного мониторинга: Распоряжение руководителя администрации Губернатора Калужской обл. от 02.03.2009 №116-ра

47 О порядке осуществления комиссией по противодействию коррупции в Ростовской обл. антикоррупционного мониторинга: Постановление Правительства Ростовской обл. от 19 апреля 2012 г. №300 // Наше время. - 2012. - 3 мая.

48 Об организации проведения социологических исследований среди различных социальных слоев населения в целях оценки уровня коррупции в Ивановской обл. и эффективности принимаемых антикоррупционных мер: Постановление Правительства Ивановской обл. от 23.11.2010 №412-п // Собрание законодательства Ивановской обл. $-2010 .-30$ нояб. №46(515).

49 О проведении антикоррупционного мониторинга: Указ Губернатора Красноярского края от 5 августа 2010 г. №146УГ // Ведомости высших органов государственной власти Красноярского края. - 2010. - 16 августа

50 Об утверждении Порядка проведения антикоррупционного мониторинга в Пермском крае: Указ Губернатора Пермского края от 25 февраля 2011 г. №14 // Бюллетень законов Пермского края, правовых актов Губернатора Пермского края, Правительства Пермского карая, исполнительных органов государственной власти Пермского края. - 2011. - 7 марта. 
спублики Дагестан «О противодействии коррупции в Республике Дагестан» в этом субъекте РФ в качестве целей антикоррупционного мониторинга предусмотрено получение данных о состоянии коррупции, коррупциогенных факторах и мерах реализации антикоррупционной политики. Вместе с тем, в постановлении Правительства Республики Дагестан «О порядке осуществления антикоррупционного мониторинга» указано, что целью антикоррупционного мониторинга в Республике Дагестан является оценка эффективности антикоррупционной политики, реализуемой на территории Республики Дагестан ${ }^{51}$. В результате принятия подзаконного нормативного акта не законодательных целей регионального антикоррупционного мониторинга оказались - оценка состояния коррупции и коррупциогенных факторов. Аналогичные противоречия усматриваются нами и таких субъектах РФ, как: Республика Татарстан, Калининградская, Оренбургская, Липецкая, Владимирская и Свердловская области, а также г. Санкт-Петербург.

Вместе с тем, как мы уже указывали выше, встречаются случаи когда цели антикоррупционного мониторинга сформулированы в подзаконном нормативном правовом акте несколько шире чем в региональном антикоррупционном законодательстве. Так, в соответствии с положениями ст. 8 Закона Республика Карелия «О противодействии коррупции» целью антикоррупционного мониторинга является измерение эффективности мер по реализации антикоррупционной политики ${ }^{52}$. Вместе с тем, в постановлении Правительства Республики Карелия «О Порядке проведения антикоррупционного мониторинга» предусмотрено несколько целей:

1) установления факторов, оказывающих влияние на ситуацию в сфере противодействия коррупции, и их оценки;

2) реализации неотложных и долгосрочных мероприятий по предупреждению и устранению коррупционных проявлений;

3) информирования органов исполнительной власти Республики Карелия, органов местного самоуправления муниципальных образований, организаций и населения о результатах, полученных при проведении антикоррупционного мониторинга ${ }^{53}$. Близкие по со-

51 О порядке осуществления антикоррупционного мониторинга: Постановление Правительства Республики Дагестан от 20 апреля 2012 г. №119 // Собрание законодательства Республики Дагестан. - 2012. - №8. - Ст. 312.

52 О противодействии коррупции: Закон Республики Карелия от 23.07.2008 №1227-3РК (ред. от 03.03.2010) // Карелия. 2008. - 5 авг.

53 О Порядке проведения антикоррупционного мониторинга: Постановление Правительства Республики Карелия от держанию противоречия правотворческого характера встречаются в нормативных правовых актах, регулирующих организацию и проведение регионального антикоррупционного мониторинга в Ярославской и Калужской областях.

Следует отметить, что в некоторых субъектах РФ цели антикоррупционного мониторинга заложенные в региональном антикоррупционном законодательстве соответствуют целям, указанным в подзаконных нормативных актах полностью (Ивановская, Ростовская и Нижегородская области, Республика Удмуртия), с небольшими уточнениями или корректировкой (Пермский и Красноярский края, Республика Якутия). Выявленные нами противоречия регионального правотворчества обусловлены тем, что их разработчики по-разному воспринимают цели регионального антикоррупционного мониторинга и специфику его правового регулирования, организации и осуществления.

В практике правового регулирования антикоррупционного мониторинга встречаются и нарушения норм юридической техники. Так, в Указе Губернатора Свердловской области, регулирующем вопросы организации и проведения регионального антикоррупционного мониторинга, в качестве цели выделено «обеспечение непрерывного наблюдения за реализацией мер по профилактике коррупции и осуществления мероприятий по устранению причин и условий, способствующих совершению коррупционных правонарушений ${ }^{54}$. Здесь очевидно при подготовке нормативного правового акта правотворческий орган нарушил юридическую правотворческую технику, он в одном предложении фактически дублирует одно и тоже положение, не подозревая того, что профилактика коррупции, в соответствии с федеральным антикоррупционным законодательством, и есть устранение причин и условий коррупционных правонарушений ${ }^{55}$.

Из приведенного выше можно сделать вывод о том, что региональные органы государственной власти по-разному определяют цели антикоррупционного

31 декабря 2009 г. №321-П // Собрание законодательства Республики Карелия. - 2009. - №12 (ч. II). - Ст. 1491.

54 О мониторинге состояния и эффективности противодействия коррупции (антикоррупционном мониторинге) в Свердловской обл.: Указ Губернатора Свердловской обл. от 13 марта 2009 г. №229-УГ // Областная газета. - 2009. 20 марта; О мониторинге состояния и эффективности противодействия коррупции (антикоррупционном мониторинге) в Свердловской обл.: Указ Губернатора Свердловской обл. от 3 ноября 2010 г. №971-УГ // Собрание законодательства Свердловской обл. - 2011. - №11-3 (2010). - Ст. 1827.

55 О противодействии коррупции: Федеральный закон 25 декабря 2008 г. №273-Ф3 // С3 РФ. - 2008. - №52 (ч.1). Ст. 6228 . 


\section{Административное и муниципальное право 8 (68) • 2013}

мониторинга. При этом они, как правило, игнорируют положение о том, что антикоррупционный мониторинг - это всего лишь измерительный инструмент, который призван отслеживать качественные и количественные показатели (динамику и состояние) коррупции, её причин и условий (коррупционных и/или коррупциогенных факторов), а также результативность антикоррупционной деятельности уполномоченных на то органов и должностных лиц, а также институтов гражданского общества и всего населения. Именно в этом его предназначение, а декларируемые в нормативных правовых актах цели регионального антикоррупционного мониторинга - это лишь основные направления деятель- ности (цели непрерывного действия), которые могут привести к наступлению желаемого результата путем постоянной ориентации поведения субъектов этой деятельности. Поэтому цель организации и проведения регионального антикоррупционного мониторинга выступает в роли стержня, вокруг которого формируются процедурные и технологические аспекты его результативного осуществления. В связи с этим становится очевидным, что необходима унификация региональных нормативных правовых актов, регулирующих организацию и проведение регионального антикоррупционного мониторинга, в том числе и при определении основных целей антикоррупционного мониторинга.

\section{Библиографический список:}

1. Бикеев И.И., Бикмухаметов А.Э., Газимзянов Р.Р. и др. Коррупция и антикоррупционная политика: Терминологический словарь / под общ. ред. Г.И. Райкова, П.А. Кабанова, Д.К. Чиркова. - М., 2010.

2. Павленко О.В. Антикоррупционный мониторинг - необходимое условие антикоррупционныхмероприятий // Следователь. - 2013. - №4.

3. Хазанов С.Д. К вопросу о формировании механизмов оценки эффективности мер противодействия коррупции в Российской Федерации // Следователь. - 2013. - №1.

\section{References (transliteration):}

1. Bikeev I.I., Bikmuhametov A.E., Gazimzyanov R.R. i dr. Korrupciya i antikorrupcionnaya politika: Terminologicheskiy slovar' / pod obsch. red. G.I. Raykova, P.A. Kabanova, D.K. Chirkova. - M., 2010. - S. 83.

2. Pavlenko O.V. Antikorrupcionnyy monitoring - neobhodimoe uslovie antikorrupcionnyh meropriyatiy // Sledovatel'. - 2013. - №4.

3. Hazanov S.D. K voprosu o formirovanii mehanizmov ocenki effek-tivnosti mer protivodeystviya korrupcii v Rossiyskoy Federacii // Sledovatel'. - 2013. - №1.

4. Storozhenko I.V. Antikorrupcionnyy monitoring organizacii ekonomicheskogo sotrudnichestva i razvitiya: publichnopravovoy aspekt organizacii protivodeystviya kriminal'nym formam korrupcii // Administrativnoe i municipal'noe pravo. - 2010. - 6. - C. 35-36. 